\title{
ЕМОТИВНА ЛЕКСИКА В РЕЛІГІЙНОМУ ДИСКУРСІ (НА МАТЕРІАЛІ НІМЕЦЬКОМОВНИХ ТРАКТАТІВ МАЙСТЕРА ЕКГАРТА)
}

Романова Н. В. Емотивна лексика в релігійному дискурсі (на матеріалі німецькомовних трактатів Майстера Екгарта).

У статті розглядається можливість вираження базових емоцій на лексичному рівні у специфічному типі текстів релігійного дискурсу - трактаті. Проаналізовано динаміку емотивної лексики в німецькомовних трактатах Майстера Екгарта 3 позиції переживання емоцій.

Ключові слова: емотивна лексика, релігійний дискурс, трактат, позитивна емотивна лексика, негативна емотивна лексика, амбівалентна емотивна лексика.

Романова Н. В. Эмотивная лексика в религиозном дискурсе (на материале немецкоязычных трактатов Майстера Экгарта).

В статье рассматривается возможность выражения базовых эмоций на лексическом уровне в специфическом типе текстов религиозного дискурса - трактате. Проанализировано динамику эмотивной лексики в немецкоязычных трактатах Майстера Экгарта с точки зрения модальности переживания эмоций.

Ключевые слова: эмотивная лексика, религиозный дискурс, трактат, позитивная эмотивная лексика, негативная эмотивная лексика, амбивалентная эмотивная лексика.

Romanova N. V. Emotional vocabulary in religious discourse (on the basis of German treatises Meister Eckhart).

The article deals with the possibility of expressing basic emotions at the lexical level in a specific type of texts of religious discourse - treatise. The dynamic of emotional vocabulary in German treatises Meister Eckhart in terms of experiencing emotions is analyzed.

Key words: emotional vocabulary, religious discourse, treatise, positive emotional vocabulary, negative emotional vocabulary, ambivalent emotional vocabulary. 
Емотивна лексика як репрезентант емоцій у мові вживається в текстах різних типів і жанрів. У релігійному дискурсі емотивна лексика $є$ одним із найважливіших засобів актуалізації уваги до змісту повідомлення, істотним компонентом розгортання й опису емотивної ситуації, своєрідним маркером експресивності висловлення чи носієм емотивної інформації про залучення людини до віри, або укріплення віри в Бога [2, с. 4,11$]$.

Дослідницька робота мовознавців у напрямку «емоції і релігія», «емотивність і духовність», «емотивна лексика і релігійний дискурс» перебуває на периферії. Утім, вивчення питань мови й релігії, мови і християнства, мови та Біблії започатковане ще в XIX ст. працями В. фон Гумбольдта, В. Вундта, М. Мюллера, О. О. Потебні [5, с. 151]. Актуальність теми зумовлюється, по-перше, відсутністю наукових розвідок про емотивність у релігійному дискурсі; по-друге, важливими експресивно-стилістичними функціями емотивної лексики в цьому типові мовлення; по-третє, відносно великим кількісним складом емотивно маркованих слів у німецькомовних трактатах найвідомішого теолога, філософа, містика Німеччини XIV ст. Майстера Екгарта.

Мета студії - окреслення семантичного наповнення емотивної лексики в названих типах письмового дискурсу рейнського генія.

Семантиу емотивної лексики досліджуватимемо у специфічних релігійних текстах - трактатах, відповідно, вважаємо за необхідне звернутися до витлумачення цього терміна й з'ясування його стосунку до релігії. Традиційне витлумачення трактату лежить у двох площинах: 1) науковій; 2) історичній. Наукове розуміння апелює до форми праці, у якій розглядається окреме питання або проблема. 3 історичної позиції трактат $\epsilon$ архаїзмом зі значенням «міжнародний договір». У протомові латині - слово tractātio вживається в чотирьох значеннях: 1) позначення дотику; 2) позначення практичного вміння й навичок; 3) позначення особливої семантики слова, слововживання; 4) позначення дискусії, витлумачення [3, с. 676]. Очевидним є те, що в німецькомовній культурі пізнього середньовіччя трактат буквально означав «обговорення, розгляд, трактування». Простежується нашарування мовлення й мислення, дидактики й гносеології, досвіду й знань.

Отже, «трактат» і «релігія» співвідносяться за формулою «мова свідомість», «когніція - духовність». Тут спільною семою є 'надприродність явища', яке потребує пояснення фахівцем - священиком чи пастиром.

3 позиції мотивації богословський трактат ставить перед собою два завдання: 1) представити свого опонента в найменш вигідному для нього світлі; 2) інкорпорувати цитати противника у «своє» розмірковування за формулою «первинні посилання - логічний розвиток - читач» [4, с. 12]. При цьому важливу роль відіграє елемент навіювання, тобто можливість нав'язати опонентові й/чи слухачам певні дії або стани [6, с. 42]. Трактат $\epsilon$ 
полемічною програмою, у якій використовуються різні методи маніпуляції читацькою думкою. Доведено, що в маніпулятивному дискурсі оцінка переважає над фактом, уплив над інформуванням, емоційне над раціональним [1, с. 17-18]. На передній план висувається проблема взаємозв’язку мови й психологічних структур мовленнєвої особистості. Ця проблема може бути й повинна стати окремим предметом дослідження. Ми ж повертаємося до типології основних методів маніпуляції. Виокремлюють лінгвістичні методи маніпуляціі, екстралінгвістичні й паралінгвістичні. Серед лінгвістичних виділяють фонетичні засоби, словотвірні, морфологічні, лексичні, синтаксичні, різні порушення норм: граматичні, лексичні, стилістичні, риторичні прийоми: повтори мовних одиниць, паралелізм, метафора, метонімія, літота, гіпербола тощо. Екстралінгвістичні пов'язані з темпом мовлення, паузацією, покашлюванням, зітханням, сміхом, плачем, жестами, мімікою, позами тощо. До паралінгвістичних, або соматичних, належать: рухи руками, «гіпнотизований» погляд (суворий, пильний або, навпаки, розм'якшувальний чи порожній, «скляний»), дотик до різних частин тіла [7, с. 4-10]. Екстралінгвістичні і паралінгвістичні методи маніпуляції характеризують усне мовлення, тому не є релевантними для нашого дослідження.

Необхідно наголосити, що Екгарт був білінгвом - латина й німецька мова. Звідси два види його трактатів - латиномовні й німецькомовні. При цьому частина німецькомовних трактатів записана екгартівськими слухачами. У цьому контексті емотивна лексика $є$ двоплановою: у ній узаємодіють «авторська семантика» й «слухацька семантика», яка $є$ результатом «інтелектуального» опрацювання усної форми релігійного дискурсу в письмову форму. На передній план висувається питання креативної співдії за формулою «автор - слухач» і водночас післядії «слухач - автор». У межах названих питань виокремлюється біхронія, тобто щільна взаємодія й узаємозумовленість минулого й теперішнього, синхронія породження емотивної інформації та іiі розуміння, діахронія фіксації цієї інформації і їі інтерпретація.

Емотивна лексика модифікується, трансформується, виконує певну стилізовану функцію, є специфічним засобом вираження колективної свідомості німецького етносу.

Окреслимо семантику емотивної лексики в емотивних ситуаціях названих трактатів ( 104640 словоформ) за принципом модальності переживання (позитивна емотивна лексика, негативна емотивна лексика й амбівалентна емотивна лексика).

Серед позитивної емотивної лексики виділяються мовні знаки зі значенням подиву й радості. Подив маніфестовано як розмаїття форм, а саме: 1) форма привертання уваги аудиторії (5): $\boldsymbol{E} \boldsymbol{y} \hat{\boldsymbol{a}}$, herzenvriunde, nû merkent den underscheit der obersten krefte, wie rehte ordentlich unde wie edellich ein ieglichiu kraft geordent ist unde gesetzet $\hat{u} f$ ir stat, unde sint doch (C) Н. В. Романова, 2013. 
einer nâtûre [8, c. 382] - «O, любі друзі, тут зверніть увагу на різницю між найвищою силою, як силою впорядковування й гармонійно впорядкованою силою, та силою, що нашаровується на неї і яка має природне походження» (тут і далі буквальний переклад на українську мову виконано нами. - Н. Р.); 2) форма уточнення думки (5): Ey $\hat{\boldsymbol{a}}$, war umbe heizet ez inslac? [8, c. 388] - «I чому це називається попадання?»; 3) форма захоплення духовним творінням (4): Eŷa, wunderlichez wesen, daz got von nihte hat geschaffen ime selben gelîh! [8, s. 385]. «О, дивні істоти, яких сотворив Бог із нічого за

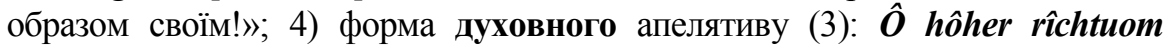
götlicher nâtûre, zeige mir dîne wege, die dî in dîner wî̀sheit geordent hâst <...> [8, с. 414-415] - «О Абсолюте, вкажи мені свої шляхи, які Ти мудро впорядкував»; 5) форма посилення ментальної дії (2): Eyâ, wunder über wunder, wenne ich gedenke an die vereinunge, die diu sêle mit gote hat! Er machet die sêle vroudenwunneclich $\hat{u} z$ ir selber ze vliezenne, wan alliu genantiu dinc genüegent ir niht [8, s. 385] - «О, диво-дивне, коли я думаю про поєднання, яке має душа з Богом! Він наповнює душу блаженством, яке витікає із Нього, якщо всі названі вище речі вас не влаштовують»; 6) форма захоплення структурою буття (1): Unt her umbe sprichel gar wol Jeremias der prophête, dô er was in grôzem lîdenne unt clagenne 'ô wie grôz unt manicvaltic sint gotes erbarmherzikeit, daz wir niht alzemâle ze nihte werden' [8, c. 433] - «I про це дуже добре говорить пророк Сремія, бо сильно страждав і мучився: 'о яка велика й різна божа милість, що ми постійно стаємо нічим'»; 7) форма інтелектуальної здогадки (1): Eyâ, nû möhte man vrâgen, wie ez sî umbe die verlorne sêle, weder si sich vinde oder niht? [8, с. 387] - «Бачу, тепер хотіли б запитати про загублену душу, чи знайде вона себе чи ні?»; 8) форма послідовності розгортання ментального процесу (1): Eŷa, nû möhte man vrâgen, wie ez sî umbe die mugentheit, obe sie mugentheit haben nâch der persônlicheit oder nach der wesenheit? [8, с. 388] - «Ну, а тепер хотіли б запитати про можливості або чи залежить можливість від особистості чи буття?»; 9) форма заперечення лаконічності інформації (1): Her $\hat{u}$ sprichet sant Dionysius: got wont in dem nihte. Ô Dionyse, daz wêre ze klein gesprochen! got wonet in dem nihtes-niht, daz $\hat{e}$ was denue niht, daz ist diu verborgen gotheit [8, с. 539] - «Святий Діонісій говорить тут: Бог мешкає в ніщо. О Діонісіє, це заднадто стисло! Бог мешкає в ніщо-ніщо, яке первісно перебувало в прихованому вигляді в божестві». У наведених прикладах більшість перелічених форм виражаються полісемічним вигуком Еуâ (18) і О̂ (4), ô (1). Емоційні й волюнтативні вигуки, як відомо, є маркерами експресивного мовлення й афективної поведінки.

Крім того, здивування в німецькомовних трактатах Екгарта відображається як когнітивна дія людини щодо будови фізичного світу: Ein heilige sprach: dich wundert der hohe des himels unde der wite des firmamentes? [8, c. 374] «Один святий запитав: тебе дивує небесна височінь і широта небозводу?», 
як оцінка ознаки предметів чи дії: Wan als wunderlich der menschen muоt ist, als wunderlich ist der wec ze gote, dâ mite er einen mit lust zuo im ziuhet unde den andern mit ungemache unde siegen, als sant Paulus wunderliche bekêret wart, dô er an dem wege was die kristen ze slahenne, unde daz er dannoch nâch sîner sêle in den dritten himel gezucket wart [8, c. 406] - «Коли настрій у людини гарний, коли іï шлях до Бога непростий, то Ісус 3 радістю приймає праведника і всі його біди й перемоги, як це трапилося зі Святим Павлом, коли він неочікувано прийняв християнство, і після цього його душа перебувала на третьому небі», як оцінка оволодіння людиною свого духовного світу: Ouch an dem tage, dar an sant Augustînus bekêret wart, dô künde er niht ersatet werden von dem wunderlichen luste, den er hete an der huote, die got der sêle leite, dâ mite er sî zuo im kêrte [8, с. 406] - «I в той день, коли Святий Августін христився, у нього був прекрасний настрій, це було на пагорбі, куди його привів Господь, щоб Августін увіровав»; як оцінка ознаки процесуальності: Lîden ist im so wunneclich, daz lîden ist im niht lîden [8, c. 441] - «Страждання в Богові таке чудове, що страждання в Ньому не страждання»; як надприродне біологічне явище (2): Zem andern mâle ist der herre Jêsus gar eins hôhen adels, wan er hât einen vater in himel âne muoter unde hât $\hat{u} f$ erden ein muoter âne vater, unde dar umbe ist sîn adel sô wunderlich, daz in keins menschen sin begrîfen mac [8, с. 407] - «По-друге, Син Божий має одне із найдивовижніших походжень: у Нього є Батько на небесах, але немає матері, а на землі у Нього є матір, але немає батька, тому Його благородство таке дивне, що ніхто із людей не спроможний цього зрозуміти»; як надприродне духовне явище: Unde welhiu sêle alsô in den willen gotes gekêret wêre unde des ireu niht suohte, in der wûrde Jûsus wunder trîben unde wunne haben [8, c. 408] - «I в якому б стані, отже, душа не вернулась до Бога, Ісус сотворив би чудо і радів би ійу»; як назву надприродного в широкому сенсі: Nû merke, waz wunders unde waz lebennes hât der mensche ûf der erden als in dem himele in gote selben! [8, с. 426] - «Пам'ятай же, що чудеса й життя людина має лише на землі, а не на небі в Богові!»; як духовний дар людини: Die grôze und undenkliche vollekomenheit unde die wunderliche vreude, die diu sêle hat von der sêliger gegenwörtikeit gotes in dem heiligen sacramente, künden alle krêativen niht einen ougenblic gegeben noch bewîsen in der wârheit [8, c. 380]«Велика й немислима досконалість і благо, які отримала душа в теперішній святості божій через Святе Письмо, зазвичай, не повідомляються й не доводяться всім творінням миттєво»; як спосіб дії (2): Waz wunders ist denne daz, daz ich leidic wirde, sô ich doch leit unt untrôst minne unt daz ouch mîn herze suochet unde mîn minne gît daz guot der crêatûre, daz gotes eigen ist? [8, с. 422] - «Дивно, що я страждатиму? так, я дійсно страждатиму i одностороння любов і моя душа шукатиме, і моя любов терзатиме душу божественної істоти?»; як вираження емоційного стану: 'Nûu dunkestû dich

(ㄱ Н. В. Романова, 2013. 
harte stark: mich hât wunder, wie dî lîden mügest nie denne dû gelîtet hast.' [8, c. 456] - «Дочко, ти мене дуже засмутила: дивуюся, як ти любиш страждати, хоч ніколи й не страждала». Частиномовна диференціація емотивної лексики в аналізованих прикладах загалом представлена іменниками (9): Lîden $^{-} 2$, luste ${ }^{+}$, minne $^{+}$, minne ${ }^{-}$, niht lîden ${ }^{+}$, wunder ${ }^{+}$, wunders ${ }^{+\mathrm{MH}}$, wunderliche vreude $^{+}$, прикметниками (7): hôhen ${ }^{+}$, leidic ${ }^{-}$, wunderlich $^{+} 4$, wunderlichen ${ }^{+}$, діссловами (7): dunken', lîden ${ }^{-2}$, niht lîden ${ }^{+}$, wundern ${ }^{+}$, wunder hân ${ }^{+}$, wunne hân ${ }^{+}$, прислівниками (3): wunderliche ${ }^{+}$, mit lust ${ }^{+}$, wunders ${ }^{+}$. Переважають іменники, всередині яких виділяються позитивні емотивні субстантиви, що свідчить про значущість позитивних емоцій.

Емоція радості мислиться як протяглість у просторі, активатором якої $\epsilon$ конкретна людина: Der niunde nutz, der an unsers herren lîcham ist, daz ist ein vreude der sêlen âne underlâz. Ein sicher samwizzicheit hât stête wirtschaft; ein luter samwirzicheit, diu unvermenget ist mit allem dem, daz kreaturlich ist, diu gît volle vreude deme herzen; wan swer dise hat, der ist vrô in gemache und in ungemache, in liebe, in leit, wan sîn ûnwendikeit vröuwet sich in deme lebenden gote [8, с. 380] - «Дев'ята користь, яку приносить наш пан Лейгам, це безперервна радість людям. Загальні знання має місцеве господарство; невелика загальна площа посівів, яка не примножує все те, що є створеним, ощасливлює тим душу; коли хтось має наділ, той щасливий в зробленому і незробленому, в кохані, в стражданні, коли ії незворотність радіс в живому Богові». У наведеному прикладі радість характеризується ступенем вияву (volle vreude), який охоплює окремі внутрішні соматичні частини організму (herzen), відносною ознакою виробничих стосунків (vrô), дією, що спрямована на суб'єкт (vröuwet sich). При цьому виокремлюється вихідне почуття людини - кохання та переживання нею цього почуття. Вираження духовної емоції радості зафіксовано в такому прикладі: Dar umbe swenne der andêhtigen sêle diu zuokunft irs küniges Jêsû Kristî durch etlichiu dinc verkündet wirt, sô fröuwet sich allez, daz in ir ist, unde des küniges reht ist, daz er würke nâch sîner hêrschaft und erfülle der sêle hoffenunge, diu sîn begert, sî ze sterken, daz si den ûzern sinnen dekeine stat gebe, iht ze würken in deheiner crêatûre âne den willen gotes [8, с. 403] - «Тому коли душі, яка пам'ятає майбутнє свого царя Ісуса Христа, будь-яка річ нагадає про Нього, то радіє все, що в ній $\epsilon, \mathrm{i}$ праведне духовне, що Він впливає своїм пануванням і наповнює душу сподіваннями, які б не забажалося, будь сильним, щоб вона не поступилася розуму, ви дієте згідно не з творінням, а волею Божою». Духовність має тут теологічний християнський характер згідно з новим ученням (Jêsû Kristî).

Персоніфікація душі та іï духовна автономність маніфестовані в прикладі: Diu sêle sol sich ouch aller gâbe gotes alse vaste an andern fröuwen als an ir selber [8, с. 408] - «3 усіх дарів божих душа має обрати піст і радіти йому як самій собі». Тут душа демонструє різні взаємодоповнюючі функції: функцію вибору й функцію емотивності. Щоправда, названі 
функції зумовлені генетично, духовно й кількісно. I саме ця зумовленість програмує душу і вона стає невільною.

Характерно, що емоційні продукування й переживання душі співвідносяться з природою Ангелів: Wan wie wol die engel in etlîcher mâze der sêle in künftigen fröuden gelîch sint, doch ist in ein ziel geselzet, über daz sie nihl komen mügent [8, с. 408] - «Загалом, Ангели схожі на душу за виявом щастя, проте у них своя ціль, через яку вони не можуть переступити». На цьому тлі емоційне та його вияв є позаземним явищем. Лексема fröuden вживається в множині, яка репрезентує одиничність. Отже, психічний світ людини чи ії душа має індивідуальність, самоцінність, цілісність.

$\mathrm{У}$ прикладі wer reht in daz houbet kême, der tête niemer keine sünde, im würde ouch diu êwige fröude sô erkant unde würde alsô gelêrt, daz er keiner predic bedürfte [8, c. 412] - «Хто по-справжньому прийде до Iсуса, той ніколи не грішитиме, він пізнає також вічне блаженство і Господа, отже, праведника не потрібно буде вчити, йому не будуть потрібні ніякі проповіді» емотивний іменник fröude розширює свою семантику до суперлативності, що межує з духовним. У семантичному процесі бере участь прикметник із темпоральним значенням êwig. Поєднання нетотожних понять «час» і «емоція» зумовлює деактуалізацію основних предметнологічних сем - 'емоційна піднесеність' і актуалізує потенційні емотивні семи - 'велике щастя'.

Швидкоплинність емоційного стану та його вияву, їх неконтрольваність індивідом репрезентовано в прикладі Lust unt fröude dunket nieman lang noch verre [8, с. 432] - «Радість і щастя ніхто довго не втримає». Тут емотивні іменники Lust i fröude являються семантично рівнозначними й функціонально експресивними.

Те, що контрастивні емоції можу трансформуватися з одного знака модальності переживання в протилежний, демонструє приклад Sîn wort ist, daz unser leit sol verwandelet werden in fröude [8, с. 428] - «Божа істина, що наше страждання перетвориться в радість».

Проблема вербалізації негативних базових емоцій у досліджуваних текстах означена більш голосно. Можна виокремити емоцію горя, емоцію гніву, емоцію сорому, емоцію провини. Причому їх презентація $\epsilon$ асиметричною. Переважає емоція горя $з$ його основним компонентом стражданням. Активаторами страждання є Бог (2): Si wölte niht geliten noch überliten hân leit unt lîden: si wil unt wölte alle zît âne underlâz lîden dur got unt güeti. Alliu ir selikeit ist liden dur got, niht gelilen hân. [8, c. 434-435] «Праведник не хоче ні страждати, ні переживати горе й муки: він хоче i хотів б завжди страждати через Бога й доброту. Все його блаженство страждання через Бога, а не пострадати через Нього»; пристрасне відношення до предметного світу, його речей: leit kumet von liebi des, daz mir schade hât benomen. Ist mir denne schade ûzerlîcher dinge leit, daz ist ein war () Н. В. Романова, 2013. 
zeichen, daz ich minne ûzerlichiu dinc unt minne wêrlîchen leit unt untröst [8, c. 422] - «Краще я розкажу про те, що всі страждання через любов до того, чого шкода. Якщо я страждаю через зовнішні речі, то це знак того, що я люблю зовнішні речі і люблю примусове страждання і невтішність»; почуття: Für baz sô spriche ich: allez leit kumet von liebi unt minne; wan minne

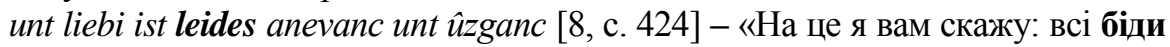
від кохання й любові; коли $є$ любов і кохання, тоді починаються страждання»; фізичний біль упродовж пологів: Allez, daz ich nû gesprochen hân, daz meinet, daz unser herre sprichet 'sô diu frouwe gebirt daz kint, sô hat si leit unt pîne, sô aber daz kint geboren ist, sô vergizzet si leides unt pîne.' unt pine. Dar umbe sprach ouch got unt manele uns in dem êwangeliô, daz wir biten den himelschen vater, daz unser fröude volkomen werde [8, с. 432] - «Усе, що я тут розповідав, стосується слів нашого Господа: 'коли жінка народжує дитя, вона страждає й мучиться, але коли дитина народилася, то біль і муки забуваються.' Про це говорив нам також і Бог, і апостоли в Свангелії, що ми просимо в небесного Отця повного щастя»; спосіб життя духовної людини: Lîden hât er, daz er minnet lîden durch got und lîdet got, unt dar umbe unt ouch dar an sô ist er gotes sûn nâch gote und in gote gebildet [8, c. 437-438]«Праведник страждає, він любить страждати через Бога, і Бог страждає, i тому, і також через це він син Божий і в Богі утворився». Емотивна лексика, що відображає страждання, ідентифікується за двома частинами мови:

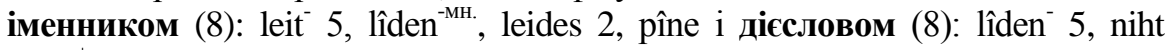
lîden ${ }^{+}$, leit hân’, pîne hân`. Співвідношення даних частин мови є симетричним 8::8, що вказує на рівнозначність предметності й динаміки емоційного стану. Специфічною ознакою можна вважати сполучуваність негативних емотивних дієслів із запереченням niht i поєднання дієслів зі значенням нейтрального стану з негативними абстрактними іменниками типу leit, pîne.

У трактаті «Das buoch der götlîchen trœstunge» (Книга Божої утіхи) актуалізується нове значення дієслова lîden - «карати», поява якого детермінована грою словоформ leit i lîde: Waz wunders ist denne daz, daz got verhenget, daz ich gar billîchen schaden unt leit lîde? [8, с. 424] - «Дивно те, що Бог карає мене за мої незначні вчинки й значні?». Пропонуючи нову поетичну техніку, Екгарт майстерно поєднує зміст (що скажу?) і форму (як скажу?), «живу» мову й «наукову», «свої» переживання й «чужі». Він дає свою оцінну точку зору того, що зображує.

Зафіксовано варіативні емотивні ситуації з емоційними вигуками, що виражають досаду, сум чи печаль (5): dô seite Moises 'ô herre, niht sende mich, dî wellest denne selber mite komen.' [8, с. 424] - «I сказав Моісей 'о Боже, не посилай мене, тобі прийдеться йти зі мною'»; Eyâ, wie sêre sie sich hinderent diss heimlichen inganges, die so lîhteklichen belibent $\hat{u} f$ liplîchen dingen! $[8$, c. 505] - «O, як же духовні матерії перешкоджають цьому таємничому входженню [душі в божественну природу], вони так легко щоденно 
залишаються на предметах!»; Daz bant der minne ist ir alze starc. Si sprichet: ach, wer mac mich getrosten? mîn ungeval ist alze grôz! [8, c. 542] - «Пута любові дуже міцні для душі. Вона говорить: ax, хто мене втішить? Моя антипатія дуже велика!». У наведених прикладах виділяються три емоційні вигуки - ach, Еуâ, ô, які вживаються зі значенням «о!». Авторське мовлення, що йде від самого Майстра, оформлено емоційним і волюнтативним вигуком Еуа̂. Мовлення опонентів чи художніх образів розпочинається вигуками асh (любов) і ô (Моісей). Отже, аналізовані вигуки слугують для передачі процесу розмови й диференціації емоційного стану мовців.

Емоція гніву розглядається крізь призму духовності, емотивності й естетичності. Та незважаючи на різні площини феномена, його номінація аналогічна - zorn. Гнів як духовна категорія пов'язується зі структурою душі та їі волюнтативом: Der dritte zorn der sêle ist, daz si got wolde sîn unt laz enkein crêatûre nirendert werc, als dâ got was in sîner êwikeit, $\hat{e}$ daz er ie crêatûre geschuof, dur daz si gotlîcher nâtûre in der einekeit gebrûchen möhte als er ê tet [8, c. 543] - «Третій гнів душі - це бажання бути Богом і не допустити жодне творіння до перетворення, як це було у первні, до того як Він створив кожну істоту, і цим душа хотіла б зламати божественну природу як Він це колись зробив».

Як категорія психічна гнів реалізується в комунікативному акті, збільшує дистанцію між комунікантами й починає домінувати поза інформаційним континуумом: Der fünfte schade ist zorn. Prüeve, lieber mensche, waz dîu ie getete in dîme zorne mit worten oder mit werken, daz soltûu bezzeren mit senftmüetigen worten. Wizzist, dî mahl daz wort geret hân in dînem zorn, bestest dî da mite, dîu wirst ein kint des ewigen tôdes [8, c. 450]«П'ятий гріх - гнів. Слідкуй, люба доню, щоб ти в гніві не скривдила ні словом, ні ділом, образу виправляй лагідними речами. Знай, що раз сказане тобою слово в гніві, знищить тебе як людину».

Естетичність гніву проявляється зовнішньо і внутрішньо. Зовнішньо гнів відрізняється через зміну пігментації шкіри обличчя. Передумовою такої трансформації є біологічна природа й загальнокультурний розвиток людини: Diu minnende sêle wirt zornic von ir selbes bekentnisse. Si hât ein antlitze enpfangen kreftecliche und ist rot unde zornic umbe daz überblîben, daz ir in got blîbet, daz si altez daz niht enist, daz got ist von nâtûre, unde daz si allez daz niht enhat, daz got hat von natûre [8, с. 542] - «Любляча душа гнівається від своєї сповіді. У неї є обличчя і воно червоне й сердите через невиокремлення, і що в неї немає того, що $\epsilon$ в Богові». Внутрішній прояв гніву передбачає наявність близького оточення. При цьому просторові параметри поширення гніву - безмежні: Nû sprechent die meister, noch sî ein nâher zorn dan daz sînen friunt haben wil sînen friunt selben und allez, daz er hat. Diu sêle sprichet, daz ir zorn sô unmêzic sî, daz er sich mit ir niht versünen möge [8, c. 542] - «Тепер Майстер говорить, є ще ближчий гнів, тому друзі Бога хочуть мати це у 
своїх друзів і у всьому, що $є$ у Бога. Душа говорить, що іiі гнів такий безмірний, що Бог не може примиритися 3 нею». Сюди додається й волюнтатив-уподібнення з сакральним: Der dritte zorn der sêle ist, daz si got wolde sîn unt laz enkein crêatûre nirendert werc, als dâ got was in sîner êwikeit, $\hat{e}$ daz er ie crêatûre geschuof, dur daz si gotlîcher nâtûre in der einekeit gebrûchen möhte als er ê tet [8, c. 543] - «Третій гнів душі - це бажання бути Богом і не допустити жодне творіння до перетворення, як це було у первні, до того як Він створив кожну істоту, і цим душа хотіла б зламати божественну природу як Він це колись зробив». Отож, емоція гніву структурована категорійно й опрацьована рейнським містиком художньо.

Ідея сором'язливості в аналізованих трактатах інтерпретується порізному. 3 одного боку, це - настанова всім членам лінгвоспільноти певної конфесії: Man solle sich des sêre schamen von herzen vor gote unde sînen engelen unt vor den liuten, daz man des iemer gewâr würde. Man schämet sich sô vaste eines gebresten an dem antlüte, daz die liute sehent îzerlichen [8, c. 446] «Слід дуже соромитися перед Богом і Його Ангелами, і перед людьми, що завжди небезпечні. Сильний сором проявляється на обличчі, так що люди бачать його зовні»; 3 іншого, - настанова для окремих верств населення, а саме молодих жінок: Niht enschame dich vor dem bibler, schäme dich vor gote unde vor allen den friunden gotes unde gewin gotliche vorhte unt verstant dich, daz got wille, wort unde werc alle gesehen hât mit sîner gotliher angesiht, unt tuo $\hat{u} f$ dîn herze, giuz $\hat{u} z e r$ dir allen dînen gebresten, und als dî̀ im geseit hâst allen dinen gebresten, so soll $d u$ in andähticlichen biten: herre, geistlicher vater, ich bite dich umbe die minne, diu Kristum an daz kriuze bant, daz ir mich wîset den nêhsten wec zuo mîner ewigen sêlikeit [8, с. 449] - «Соромся перед священиком, соромся перед Богом і перед усіма друзями Бога i бійся Бога $\mathrm{i}$ зрозумій, чого хоче Бог, слово і діло нічого не сховається від Нього, піклуйся про свою думку, сказане, а якщо ти сказав Богу про свої таємниці, то мусиш подумки молитися: Царю, духовний Отче, я прошу тебе про безмежну любов, про найкращий шлях до мого вічного блаженства» i, зрештою, коментар на основі інкорпорованого тексту: Er sprichet 'ach mich armen man, wie mac ich mich sô wol schämen vor den ougen gotes, daz ich sô lange geistlichen schin hân gehabt und ich sô wenic bevunden hân götlicher heimlicheit [8, с. 463] - «Священик сказав 'ах я нещасний чоловік, як же я міг так осоромитися перед Богом, що так довго видавав себе за святого і так мало знайшов Божих таємниць'». У першому прикладі зберігається традиційний підхід до тлумачення сорому (sich schamen), який супроводжується елементами новизни (des sêre, von herzen), що кільцюють у синтаксичній конструкції дієслово sich schamen - «соромитися». Другий приклад $\epsilon$ репрезентантом інноваційного підходу, що виражається за допомогою дієслівної словоформи enschame dich зі значенням «не соромся», іменникового деривата bibler зі значенням «священник, проповідник, пастор, тлумач Біблії», заперечувальної частки Niht у препозиції до названої дієслівної 
словоформи та конвергенції синсемантичної лексики (vor, unde, vor, allen, den, unde, unt, dich, daz, unde, alle, mit, sîner, unt, ûf, dîn, ûzer, dir, dînen, und, als, dû, im, allen, dînen, so, du, in - усього 28) у постпозиції до слоформи schäme dich, яка конституює форму імперативу. Стосовно третього прикладу, то тут реалізується традиційний підхід з елементами самооцінки (sô wol).

Оскільки трактати Майстера Екгарта присвячені проблемам духовності, то динаміка семантичного розвитку провини та іï лексичного рівня перебуває в зародковому стані й може бути охарактеризована як одновекторна гріхопадіння людини в широкому сенсі слова: Si sprach 'daz erbarme got, daz ich des niht getan hân alle mîne tage.' Er sprach 'daz dû mir hie die schulde gist, daz ist mir leit, daz ich dich gehindert habe.' Si sprach 'ja, ich gibe iu die schulde und allen crêatûren' [8, с. 458] - «Дочка сказала: 'милостивий Бог, що я цього не робила в своїму житті.' Батько відповів: 'цим ти завдячуєш мені, що не страждала, що я тобі перешкоджав.' Вона промовила: 'Згодна, тату, я завдячус вам і всім творінням’». У наведеному прикладі лексема schulde не лише розширює своє значення, але й трансформується в площину етики та зазнає радикальних функціональних зрушень - виражає дію. Схематично ця трансформація має такий вигляд: соціально-психологічне $\rightarrow$ етичне; провина $\rightarrow$ завдячувати; іменник $\rightarrow$ дієслово.

Емоція страху посідає найнижчий щабель серед аналізованих негативних базових емоцій. Вона виражається дієсловом vorhten зі значенням «боятися (чогось, когось)». Джерело страху локалізоване в сакральній сфері та уособлено Богом-Отцем. Актуалізація страху реалізується в ментальній області мовця: Niht enschame dich vor dem bibler, schäme dich vor gote unde vor allen den friunden gotes unde gewin gotliche vorhte unt verstant dich, daz got wille, wort unde werc alle gesehen hât mit sîner gotliher angesiht, unt tuo $\hat{u} f$ dîn herze, giuz $\hat{u} z e r$ dir allen dînen gebresten, und als dî̀ im geseit hâst allen dînen gebresten, so soll du in andähticlichen biten: herre, geistlicher vater, ich bite dich umbe die minne, diu Kristum an daz kriuze bant, daz ir mich wîset den nêhsten wec zuo mîner ewigen sêlikeit [8, c. 449] (див. переклад українською мовою вище). Доходимо висновку про те, що духовне, когнітивне й емоційне тісно взаємодіють, узаємозв'язані.

Амбівалентність емоційного стану зафіксовано у прикладі Der aber des niht enweiz, der lachet unt spottet mîn unt ich erbarme mich über in [8, с. 447-448] - «Але філософ не знає, що таке «ніщо», він смісться і висміює мене і мені жаль його». Тут стикаються опозиційні поняття «емоція» і «поведінка». Вододіл між ними $є$ розмитим. Більш того, інтенсивність вияву позитивного емоційного стану тотожна експресивній поведінці, наслідки якої не можна передбачити. Високо духовна людина ставиться до названих явищ із жалем (erbarme mich). 3 позиції сучасної психології жаль - це прихована форма агресії. Опозиційність психічного й соціально-психологічного породжує емоційне (негативний сенс).

Слід зазначити, що частота функціонування емотивної лексики в (ㄱ Н. В. Романова, 2013. 
німецькомовних трактатах Екгарта є низькою - 0,11\%, що свідчить про специфіку емотивної лексики, генералізацію іiі семантики й наближення до термінів, редукцію емоційно-релігійних концептів. Аналіз емотивних ситуацій і семантики емотивної німецькомовної лексики показав, що в трактаті, як типі тексту, існують певні обмеження у вживанні названих лексичних одиниць: предметність, дія, ознака, експресивність. Емоційне, а не логічне відчуття проблеми духовності автором (Екгартом) дає змогу виокремити емотиви-номінативи, емотиви-дескриптиви, емотиви-афективи.

\section{Література}

1. Беляева И. В. Феномен речевой манипуляции : лингвоюридические аспекты : автореф. дис. ... д-ра филол. наук : спец. 10.02.19 «Теория языка» / И. В. Беляева. Ростов-Д., 2009. - 40 c.

2. Бобырева Е. В. Религиозный дискурс: ценности, жанры, стратегии (на материале православного вероучения) : автореф. дисс. ... д-ра филол. наук : спец. 10.02.19 «Теория языка» / Е. В. Бобырева. - Волгоград, 2007. - 38 с.

3. Латинско-русский словарь / [сост. А. М. Малинин]. - М. : Госиздат иностр. и нац. словарей, 1961. - 764 с.

4. Луховицкий Л. В. Основное богословско-полемическое сочинение патриарха Никифора Константинопольского «Apologeticus atque antirrhetici» : опыт комплексного историко-филологического анализа : автореф. дис. ... канд. филол. наук : спец. 10.02.14 «Классическая филолология» / Л. В. Луховицкий. - М., 2010. - 22 с.

5. Пономаренко Л. Г. Біблеїзми як семантико-стилістична категорія української мови (на матеріалі фразеологічних словників XX ст.) / Л. Г. Пономаренко // Вісник Запорізького національного університету. Філологічні науки. - Запоріжжя : ЗНУ, 2007. - № 1. - C. 151-158.

6. Сорокина А. С. Языковое манипулирование в различных типах англоязычного дискурса / А. С. Сорокина // Лингвистические и экстралингвистические проблемы коммуникации : Теоретические и прикладные аспекты. - Саранск : Изд-во Мордов. ун-та, 2011. - Вып. 8. - С. 38-49.

7. Шуберт Э. Э. Дискурсивные единицы, уровни, приёмы и принципы речевого воздействия в когнитивном аспекте : автореф. дис. ... канд. филол. наук : спец. 10.02.19 «Теория языка» / Э. Э. Шуберт. - Краснодар, 2006. - 24 с.

8. Pfeiffer F. Deutsche Mystiker. Bd. 2 : Meister Eckhart / Franz Pfeiffer. - Göttingen : Vandenhoeck u. Ruprecht, 1906. - 687, [3] s. 